chairman of the committee, on whom devolved much of the detail work of furthering celebrations and kindred things relating to Iowa's first hundred years as a state. The committee had of state funds $\$ 16,000$ and left of this a balance of $\$ 2,145.44$ unused. From the sale of the Iowa commemorative half-dollar coin there was realized about $\$ 195,000$ profit, which will go to historical purposes. A permanent committee of three has been named by Governor Robert D. Blue to determine the historical purposes to which the fund will be devoted, as designated by the act of congress. The members of the committee are Judge Frederic M. Miller, former supreme justice of Iowa, Dean Martin L. Tollefson, of the law school of Drake University, both of Des Moines, and Dean Mason Ladd, college of law of the State University of Iowa.

\title{
IOWA'S MEDIUM LAKE RENAMED
}

Lake Five Island at Emmetsburg, in Palo Alto county, is the new name for Medium lake, heretofore so well known. The change was determined upon locally in 1946 and recommended by the state conservation commission. Now the United States division of geography, at Washington, made the designation official as of August 10 last. Hereafter all state and Federal maps and documents will bear the new name. The lake is a quarter of a mile to a mile wide, and extends northeast from Emmetsburg five miles.

The new "Book of Des Moines" by Ilda M. Hammer, published by the City Board of Education, contains much assembled material of a historical nature concerning Des Moines and Iowa, attractively presented, representing data gleaned from a wide number of sources by the author. The volume will have especial value as a text book in Des Moines public schools and will be found in many private libraries. A most valuable feature is the group of suggestions following the close of each chapter for the class use and treatment of the subjects included. It is profusely illustrated from authentic photographs. 
Copyright of Annals of Iowa is the property of State of Iowa, by \& through the State Historical Society of Iowa and its content may not be copied or emailed to multiple sites or posted to a listserv without the copyright holder's express written permission. However, users may print, download, or email articles for individual use. 